\section{Nilai-Nilai Kearifan Lokal Melalui Tari Galombang Gaya Sasaran: Studi Sasaran Sebagai Sarana Pendidikan Kultural}

\section{Nerosti ${ }^{1}$}

Program Studi Seni Tari, Jurusan Sendratasik, Fakultas Bahasa dan Seni, Universitas Negeri Padang

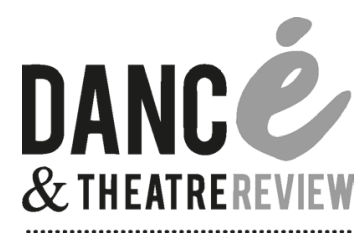

jurnal tari, teater, dan wayang volume 2 number 1, May 2019 page $35-41$

\begin{abstract}
This article aims to discuss the issue of Minangkabau local wisdom manifested in Galombang dance activities in the context of the target style. The existence of pencak silat targets is very meaningful for Minangkabau men because the target is not only a means of physical endurance training but also a basis for cultural education for Minangkabau people. Thus, the problem that will be expressed in this article is about the importance of the target for men in Minangkabau as a means of educating local wisdom, by expressing the implementation of local wisdom values through the target-style Galombang dance, and also explaining the extent to which values of the local wisdom is manifested in today's Galombang dance performances. Sasaran and Galombang dance are two things that are interconnected in building the values of local wisdom in Minangkabau. This cultural activity has been started since the past when the royal system ruled in Minangkabau. In turn, the target as a forum for cultural education that contains local wisdom values becomes the place to produce Galombang dance, so that the values of local wisdom are manifested in the target-style Galombang dance.
\end{abstract}

Keywords: local wisdom values; Sasaran; Sasaran Style of Galombang dance

\section{Pendahuluan}

Galombang hampir dimiliki oleh setiap nagari di Minangkabau. Ditarikan oleh puluhan lelaki dalam bentuk dua baris berbanjar ke belakang dan dipersembahkan untuk menyambut tamu yang dihormati. Pada masa dahulu Tari Galombang untuk menyambut tamu yang dihormati pada pesta alek nagari dan peresmian sasaran. Sasaran yang merupakan sarana penting bagi mendidik anak muda, baik secara fisik maupun mental. Oleh karenanya, perasmian sasaran hampir sama dengan perasmian sebuah sekolah baru. Oleh sebab itu, pada awal perkembangan Galombang tidak menggunakan istilah tari namun disebut Silek Galombang. Nasir Datuk Rajo Putih menjelaskan bahwa Galombang diartikan alunan air laut (wawancara 4 April 2010). Galombang juga merupakan kreativitias dalam kumpulan silat dengan menggunakan tempo, ruang, dan tenaga (wawancara dengan Musra Dahrizal, 10 Juni 2010).

Membicarakan tari Galombang tidak terlepas dari sasaran. Di sasaranlah anak muda Minangkabau dididik secara nonformal sebagai pendewasaan diri sebagai anak lakilaki. Banyak nilai-nilai yang dapat diambil dalam proses pembelajaran di sasaran nilai-nilai tersebut merupakan nilai-nilai budaya yang layaknya disebut dengan nilainilai kearifan lokal atau local genius. Dalam disiplin antropologi dikenal dengan istilah local genius. Menurut Ayatrohaedi (1986: 1819), local genius ini merupakan istilah yang mula pertama dikenalkan oleh Quaritch Wales.

1 Alamat korespondensi: Jln. Enggang 6. No 5. Parupuk Tabing Padang. Kode Pos 25171, Sumatera Barat. E-mail: nerosti@fbs.unp.ac.id; HP: 082169604446 
Para antropolog membahas secara panjang lebar pengertian local genius ini, antara lain Haryati Soebadio yang mengatakan bahwa local genius adalah juga cultural identity, identitas/kepribadian budaya bangsa yang menyebabkan bangsa tersebut mampu menyerap dan mengolah kebudayaan asing sesuai watak dan kemampuan sendiri. Sementara Moendardjito (dalam Ayatrohaedi, 1986:40-41) mengatakan bahwa unsur budaya daerah potensial sebagai local genius karena telah teruji kemampuannya untuk bertahan sampai sekarang.

Kearifan lokal yang dikenal dengan istilah local genius merupakan suatu kekayaan budaya lokal yang mengandung falsafah hidup atau pandangan hidup (way of life) yang mengakomodasi kebijakan dan kearifan hidup. Indonesia yang dikenal sebagai wilayah Nusantara memegang teguh masalah keharmonisan sosial. Hampir semua budaya mengenal prinsip gotong royong dan toleransi. Kearifan lokal itu berlaku secara lokal pada budaya atau etnik tertentu. Namun, di zaman yang serba berubah ini tidak menutup kemungkinan terjadinya lintas budaya (cross culture) atau lintas etnik sehingga membentuk nilai budaya yang bersifat nasional. Sebagai contoh, hampir di setiap budaya lokal di Nusantara dikenal kearifan lokal yang mengajarkan gotong royong, toleransi, etos kerja, dan sebagainya. Pada umumnya etika dan nilai moral yang terkandung dalam kearifan lokal diajarkan turun-temurun, diwariskan dari generasi ke generasi melalui tradisi oral atau sastra lisan dan pengamalan yang berlaku secara alami di tengah masyarakat, baik dalam bentuk folklore dan repertoire, maupun manuskrip. Kearifan lokal adalah segala sesuatu yang dimiliki oleh masyarakat lokal di daerah tertentu, merupakan ciri keaslian dan kekhasan daerah tersebut tanpa adanya pengaruh atau unsur campuran dari daerah lainnya.

Secara umum kearifan lokal dibedakan menjadi dua, yaitu kearifan lokal yang dapat dilihat dengan mata (tangible) seperti objekobjek budaya, warisan budaya bersejarah dan kegiatan keagamaan, dan kearifan lokal yang tidak dapat dilihat oleh mata (intangible) yang berupa nilai atau makna dari suatu objek atau ritual budaya yang sangat mempengaruhi pola kehidupan masyarakat itu sendiri. Walaupun ada upaya pewarisan kearifan lokal dari generasi ke generasi, tidak ada jaminan bahwa kearifan lokal tetap kukuh menghadapi globalisasi yang menawarkan gaya hidup yang makin pragmatis dan konsumtif. Secara faktual dapat kita saksikan bagaimana kearifan lokal yang sarat kebijakan dan filosofi hidup nyaris tidak terimplementasikan dalam kehidupan masyarakat seperti yang dapat kita lihat dalam masyarakat sendiri sering terjadi tindak kekerasan yang berlawanan dengan nilai toleransi. Dalam konteks perubahan nilai sosiokultural juga terjadi pergeseran orientasi nilai. Masyarakat cenderung makin pragmatis dan makin berorientasi pada budaya uang serta terperangkap dalam gaya hidup konsumtif yang disodorkan kekuatan global kapitalisme. Dalam realitas Indonesia kini, secara ekstrem dapat dikatakan bahwa kearifan lokal yang kita miliki mirip benda pusaka, yang kita warisi dari leluhur, kita simpan dan kita pelihara, tetapi kita tidak mampu mengimplementasikannya dalam kehidupan nyata sehingga pusaka tersebut sia-sia merespon tantangan zaman yang telah berubah.

Di Minangkabau, nilai-nilai kearifan lokal tetap kekal dalam setiap aktivitas budaya masyarakat. Meskipun telah mengalami degradasi karena perkembangan masyarakat pendukungnya namun nilai-nilai kearifan lokal tersebut tetap ada dalam berbagai macam seni budaya tradisional. Bagaimanapun, nilai-nilai kearifan lokal yang terkandung dalam budaya masyarakat tersebut perlu digali melalui warisan yang masih ada, salah satunya adalah melalui Tari Galombang. Tari Galombang yang merupakan tari tradisional pada mulanya hanya ditarikan oleh laki-laki saja dengan gaya pencak silat, yang dahulu dikenal dengan silek galombang. Silek Galombang merupakan mata rantai dari keberadaan sasaran di Minangkabau, yang tumbuh dan berkembang dalam sistem sosio-budaya masyarakat yang mengamalkan adat dengan sistem matrilineal. 
Bagaimana peranan sasaran tersebut dalam memperkuat nilai-nilai kearifan lokal dapat dijelaskan sebagai berikut.

\section{Sasaran Sebagai Sarana Pendidikan Non-Formal Bagi Anak Laki-Laki Minangkabau}

Sasaran sebagai badan organisasi pendidikan secara tradisional dan sebagai gelanggang permainan para belia dalam kampung, dipimpin oleh seorang pangkatuo, biasanya dirangkap oleh dubalang, suatu jawatan pembantu penghulu dalam kepemimpinan tradisional. Di sasaran silat berlangsung proses sosialisasi dari lingkungan keluarga di rumah gadang dengan rekan sebaya (akhir baligh). Proses sosialisasi terus berlangsung dengan angkatan yang lebih tua, berkaitan dengan ini dijelaskan oleh Kartodirdjo (1996: 38) bahwa sejak dilahirkan, individu di lingkungan kehidupan budaya Minangkabau, secara terus menerus mengalami sosialisasi. Proses ini berupa internalisasi pengetahuan, ketrampilan, kepercayaan dan nilai-nilai. Maka berkembanglah ia sebagai pendukung kebudayaan. Dia merupakan produk dalam proses belajaryang terus menerus mengadakan interaksi satu sama lain. Akumulasi pengalamannya, termasuk pelembagaan pada dirinya, nilai-nilai budaya masyarakat menumbuhkan suatu kepribadiannya sendiri.

Sasaran merupakan lambang eksistensi sebuah kampung dengan kaumnya. Apabila sasaran milik kaum itu baik, maka penghulu beserta kaumnya disegani oleh orang lain. Inilah sebabnya mengapa pada zaman dulu di Minangkabau setiap lelaki harus menguasai silat dan pencak. Datuk Putih (wawancara 4 April 2010) mengatakan bahwa antara silat dengan pencak sangat berbeda. Silat merupakan seni bela diri praktis untuk mengalahkan lawan secepat mungkin, sedangkan pencak, dalam bahasa Minangkabau disebut "pancak" atau "mancak" yang merupakan seni silat untuk keperluan pertunjukan di arena silat yang disebut juga pamedanan. Gerak-gerak pokoknya tetap gerak-gerak silat, tetapi disusun dan diberi variasi atau hiasan gerak (bunga silat) sesuai dengan tujuannya, sehingga mengabaikan segi efektivitas, yang menjadi elemen utama dalam silat. Menurut tradisi di sasaran, seseorang baru dapat belajar silat setelah dia mahir bermain pancak atau mancak. Menurut Sedyawati (1981: 68-74), kata pancak atau mancak berasal dari kata dasar ancak (indah) yang mendapat awalan pa atau ma (pe atau me), sehingga menjadi pa-ancak dan maancak. Huruf vokal yang berdekatan, sering dibaca atau diucapkan satu saja. Sehingga paancak dan maancak menjadi pancak dan mancak, mempunyai konotasi memperindah.

Di masa ini kegiatan sasaran dan sebagai bukti bahwa silek galombang yang sekarang dikenal dengan tarian Galombang sangat berkembang dengan jayanya. Kondisi tersebut ada dalam petatah petitih Minangkabau, yaitu:

Tagak bakampueng mambalo kampueng. Tagak basuku mambalo suku. Tagak banagari mambalo nagari. Tagak babangso mambalo bangso. Musueh indak bulieh dicari, basuo pantang diilakkan.

(Tegak berkampung memelihara kampung. Tegak bersuku (matriclan) memelihara suku. Tegak bernagari memelihara nagari. Tegak berbangsa membela bangsa. Musuh tidak boleh dicari, kalau bertemu pantang menghindarinya).

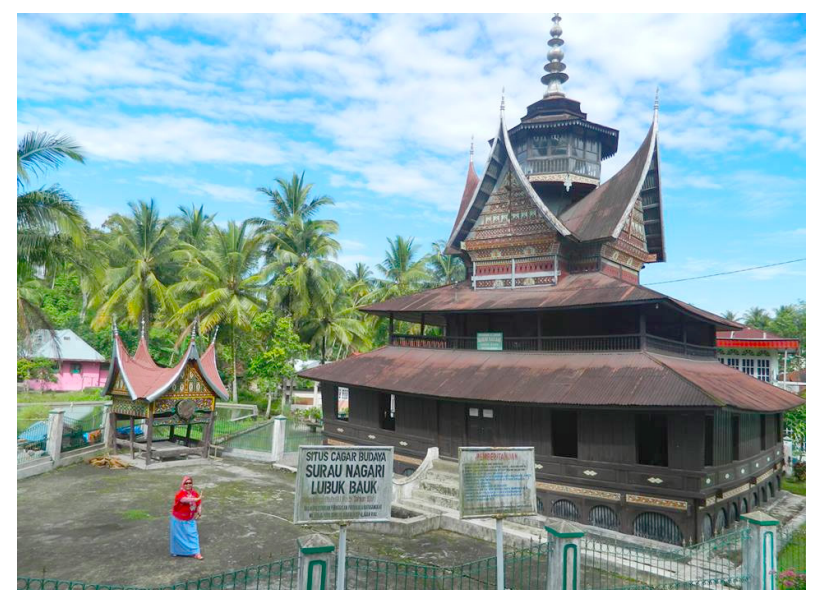

Gambar 1. Surau lama di Nagari Lubuk Bauk Tanah Datar merupakan cagar budaya yang dulu digunakan untuk belajar, mengaji dan belajar silat. Halaman surau berfungsi sebagai sasaran, di tingkat dua adalah tempat tidur bagi anak laki-laki. (Dokumentasi Nerosti, 6 Agustus 2014) 
Ungkapan di atas merupakan tujuan pendidikan tradisional bahwa sasaran untuk mendidik seseorang menjadi pahlawan atau perwira yang disebut parewa, yaitu orang yang berbudi luhur, berani menegakkan kebenaran, tidak sombong tetapi mengetahui harga diri, selalu waspada atau mengendalikan diri, tidak melanggar norma-norma masyarakat di tempat ia berada. Istilah parewa, mempunyai konotasi negatif, setelah perang Paderi, yang berpengaruh kuat terhadap masyarakat. Parewa semula istilah yang dipakai pemudapemuda kesatria dari kalangan adat yang berpakaian serba hitam sewaktu acaraacara besar (Radjab, 1968: 35; Martamin, 1981:180; Jamal, 1986:13). Bangunan paling bawah adalah tempat sembahyang dan belajar membaca Al-qur'an. Tingkat dua adalah tempat tidur, dan bangunan paling atas adalah tempat azan, manakala halaman surau pula adalah tempat belajar silat.

Setelah terjadinya revolusi agama Islam pada abad ke-9 (masa Perang Paderi, 18031837) maka berkembang pula masjid (Hamka, 2006: 14). Masjid merupakan unsur Islam yang dapat berintegrasi ke dalam kebudayaan Minangkabau dibanding surau yang lebih berkait rapat dengan kaum dan suku. Makanya dikenali dengan istilah surau kaum. Masjid kemudian menjadi salah satu identitas penting bagi sebuah nagari. Selepas Perang Paderi, semakin banyak masjid didirikan di Minangkabau. Sudah menjadi kebiasaan di Minangkabau bahwa sebuah surau terletak berdekatan dengan masjid. Masing-masing mempunyai fungsi sendiri: fungsi surau berkait dengan aktivitas keagamaan seluruh kaum dalam satu korong atau dusun, sementara fungsi masjid terkait dengan aktivitas keagamaan seluruh nagari.

Berdasarkan penjelasan di atas dapat disimpulkan bahwa kehadiran sasaran lebih diperkuat dengan berkembangnya agama Islam di Minangkabau. Surau yang tadinya hanya merupakan surau kaum kemudian seiring dengan berkembangnya Islam dibuatlah masjid, sebagai tempat peribadatan yang dapat menghimpun umat Islam lebih banyak untuk beribadah. Keberadaan masjid merupakan salah satu syarat eksistensi sebuah nagari. Syarat berdirinya nagari adalah babalai mamusajik, balabuah batapian (mempunyai balairung, masjid, lebuh raya dan perigi tempat mandi).

Sasaran dipimpin oleh seorang guru silat yang mempunyai ilmu silat secara lahir dan batin. Lahir adalah kemahiran bersilat dengan senjata, sedangkan secara batin mereka sudah menguasai ilmu silat yang tinggi, dalam istilah Minangkabau disebut tau jo garak jo garik. Maksudnya, bagi orang yang mempunyai niat jahat maka mereka sudah tahu, garak adalah perjalanan batin seorang guru silek yang juga dipanggil tuo silek. Bahkan tuo silek sering melakukan perang batin dengan guru silat yang lain. Tanpa senjata mereka boleh mematikan lawan, dalam silat disebut dengan putuih ma'rifat. Generasi kedua setelah guru silat adalah guru-guru mancak atau tari tradisional, yang dalam upacara tersebut ikut serta sebagai penari Galombang.

\section{Kekuatan Tari Galombang Gaya Sasaran}

Gerakan tari yang lebih banyak dilakukan dalam Tari Galombang ialah gerak menyongsong seperti ombak yang bergulung-gulung menuju pantai. Dalam acara penyambutan tetamu yang dihormati, tetamu yang datang disambut secara bergelombang atau beruntun dengan teratur sampai menuju ke tempat duduknya, bagaikan sebuah sampan atau sekoci yang dibawa gelombang ke pantai dengan sukacitanya. Pepatah adat mengatakan "samo naiek jo galombang, samo turun jo sipocong". Maknanya, tamu-tamu yang datang itu sederajat dengan orang-orang yang menanti. Kesamaaan derajat ini dibuktikan bahwa di dalam kehidupan ibarat menempuh gelombang, ada naik-turunnya. Naiknya seperti pergerakan gelombang di laut yang kelihatan indah, turunnya seperti sipocong yaitu buih yang terlihat sesudah ombak dan menghempas ke pantai lalu hilang ditelan pasir (MID Jamal, 1982: 21). Hal demikian seperti dijelaskan oleh seniman tradisi berikut:

Galombang yang dikatakan meniru gerak alunan gelombang di laut 
tersebut, merupakan hasil daripada kreativitas pergerakan silat dimana ketika penari serempak bergerak dalam aras tinggi, kemudian serempak pula bergerak dalam aras rendah secara bersama, maka terlihat seperti gelombang di lautan. (Wawancara dengan Musra Dahrizal dan Nasir Datuk putih, 5 Juni 2010).

Berdasarkan pendapat di atas, galombang sebagai alunan air di laut dan galombang sebagai variasi gerak silat samasama mempunyai kebenaran dan layak untuk dikukuhkan sebagai terminologi tari Galombang. Terdapat dua jenis tari Galombang tradisional, yang pertama dalam bentuk satu arah adalah Galombang Manyambuik seperti Galombang Duo Baleh dan Silek Galombang. Galombang Duo Baleh karena ditarikan oleh 12 orang penari, dan Silek Galombang karena berasal dari aktivitas silat. Silat bagi anak lelaki di Minangkabau merupakan ilmu bela diri yang mesti dipelajari. Proses pembelajaran silat berlangsung di surau-surau. Anak lelaki yang berumur tujuh tahun tidak lagi tidur di rumah, tetapi tidur di surau. Setelah shalat Maghrib hingga shalat Isya, mereka belajar membaca Al-qur'an, lalu setelah shalat Isya hingga tengah malam mereka akan belajar ilmu agama dan juga belajar silat di halaman surau. Guru mengaji di surau juga seorang guru silat yang mahir bersilat secara fisikal dan juga mempunyai ilmu silat secara batin. Dari aktivitas mengaji dan belajar silat di surau, berkembanglah arena silat. Tempat berlatih dan belajar silat tersebut di Minangkabau disebut sasaran silat (arena belajar silat). Hal ini berlaku sesuai dengan bunyi pepatah Minangkabau: "kok tibo alek basongsong, kok pulang alah balapeh" yang artinya jika tamu tiba disongsong, jika pulang akan dilepas dengan hati suci. Tari Galombang dua arah ini terdapat di Tanjung Ampalu dan di Pariaman disebut Galombang Lu Ambek (Hartati, 1999; Zulkifli, 2003; Navis, 1986; Soedarsono, 2003).

Kelompok Tari Galombang yang dipimpin oleh seorang komando itu menggunakan gerak-gerak persilatan, didukung oleh ekspresi kuat dan gagah perkasa. Dalam pergerakan galombang masih melakukan pergerakan silat bahkan menggunakan pisau, yakni senjata berupa kayu yang dilemparkan oleh penari ke pinggir, dan mereka terus bertarung. Namun pertarungan tersebut hanya berupa suatu persembahan yang juga memamerkan kelihaian bersilat semata, bukan silat yang saling membunuh. Pergerakan menyerang dan menangkis tersebut adalah ciri-ciri pada masa penjajahan. Menurut informan, sebelum Indonesia dijajah Jepang (1942), pertunjukan ini betul-betul lebih menampakkan adu kekuatan (fisik dan batin). Persembahan Luambek yang terkategori ke atas galombang manyongsong dengan ciri khas pergerakan menyerang dan menangkis itu, menurut Soedarsono (2002: 317-318), sebelum kemerdekaan penting dan harus dihadirkan pada upacara batagak penghulu, yaitu pengangkatan penghulu baharu. Upacara tarian ditutup dengan penyuguhan sekapur sirih kepada tamu.

Permainan mereka yang seperti demikian semakin menunjukkan eksistensi budaya silat di Minangkabau, seperti diuraikan Bart Barendregt (1995: 113):

Silat (martial art) merupakan suatu bagian dari pendidikan tradisional Minangkabau di Sumatera Barat. Melalui pelajaran silat seorang Minangkabau bisa menjadi 'anggota masyarakat secara penuh'. Pada satu sisi silat adalah sebuah gambaran kebudayaan Minangkabau dan di sisi lain adalah jembatan budaya. Peserta-peserta silat mencerminkan tentang masyara-

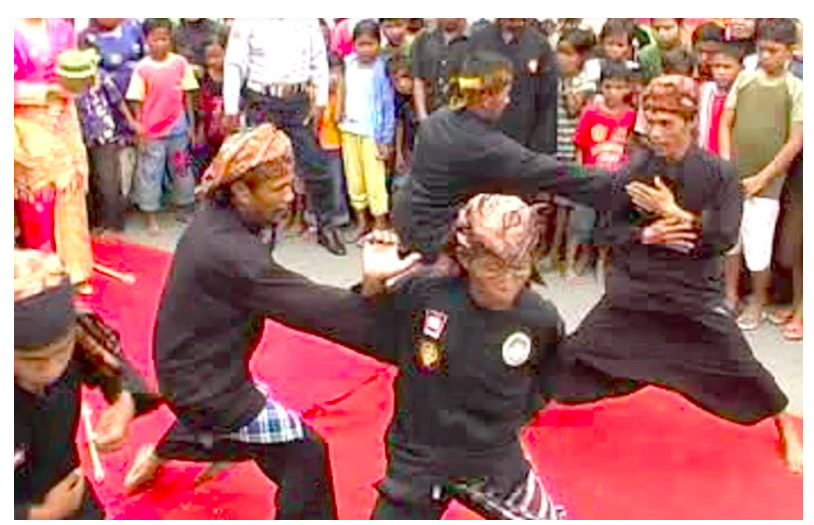

Gambar 2. Pergerakan "Ragak" dipersembahkan di akhir Tari Galombang Koto Tangah pada upacara penabalan penghulu Suku Jambak.

(Dokumentasi Nerosti, 2008) 
kat, dan hubungan-hubungan antara mikro kosmos, tubuh mereka sendiri, dan makrokosmos.

Tari Galombang gaya sasaran yang dipertunjukkan oleh laki-laki terasa masih kuat menghargai kebudayaan lokal, dan ada keinginan untuk membantu memberikan rasa identitas kepada masyarakat (Kuswarsantyo dalam Timbul, 2009: 118). Keseragaman gerak adalah semangat memperjuangkan hidup yang berawal dari memperjuangkan kampung, mengamalkan pembangunan karakter. Terdapat dua esensi penting dalam membangun karakter bangsa yaitu esensi kompetitif dan inovatif (Hatta Rajasa dalam http://www.setneg.go.id). Esensi kompetitif sangat terekspresi dalam pola formasi penari dua berbanjar dengan berpasangan.

Galombang yang lahir dari sasaran itu telah berhasil menanamkan sikap rasa tanggung jawab untuk melestarikan apa yang ditanamkan secara turun temurun dari mamak ke kemenakan, sebagai pasak kampung pagar nagari. Oleh karena itu, setiap kampung pada zaman dahulu mempunyai sasaran (Sedyawati, 1981: 72). Sasaran merupakan lambang eksistensi sebuah kampung dengan kaumnya. Apabila sasaran milik kaum itu baik, panghulu beserta kaumnya disegani oleh orang lain. Inilah sebabnya mengapa pada zaman dahulu di Minangkabau setiap laki-laki harus menguasai silat dan pencak (wawancara dengan Datuak Putih, 6 Juni 2010). Oleh sebab itu, pada masa ini kegiatan sasaran sebagai bukti bahwa silek galombang yang sekarang dikenal dengan tari Galombang sangat berkembang dengan jayanya. Perihal ini disebutkan dalam petatahpetitih Minangkabau, yaitu:

Tagak bakampueng mambalo kampueng. Tagak basuku mambalo suku. Tagak banagari mambalo nagari. Tagak babangso mambalo bangso. Musueh indak bulieh dicari, basuo pantang diilakkan.

(Tegak berkampung memelihara kampung. Tegak bersuku (matriclan) memelihara suku. Tegak bernagari memelihara nagari. Tegak berbangsa membela bangsa. Musuh tidak boleh dicari, kalau bertemu pantang menghindarinya).

Ungkapan di atas merupakan tujuan pendidikan tradisional di sasaran untuk mendidik seseorang menjadi pahlawan atau perwira (dalam bahasa Minangkabau disebut "perewa") yang berbudi luhur, menegakkan kebenaran, tidak sombong, tetapi mengetahui harga diri, waspada atau mengenali diri dan mengendalikan diri, tidak melanggar normanorma masyarakat di tempat ia berada (Radjab, 1968; Mardjani Martamin, et al., 1981; MID. Jamal, 1986: 13) Istilah "parewa" mempunyai konotasi negatif, setelah Perang Paderi, yang berpengaruh kuat terhadap masyarakat. Parewa semula adalah istilah yang dipakai pemuda-pemuda kesatria dari kalangan adapt yang berpakaian serba hitam, sewaktu terjadi perang saudara akibat pemurnian ajaran-ajaran Islam oleh kalangan Paderi yang ditendang oleh kalangan Adat dan Istana Pagaruyung (Mid Jamal, 1986: 17).

\section{Penutup}

Berdasarkan uraian yang dikemukakan, disimpulkan bahwa Tari Galombang gaya sasaran merupakan rekonstruksi kegiatan sasaran di Minangkabau dalam sistem matrilineal, yang mempunyai nilai budaya yang pantas diwarisi oleh generasi muda dapat dikemukakan melalui ciri-ciri sebagai berikut: (1) Tari Galombang menunjukkan semangat kebersamaan adu kekuatan di bawah suatu pimpinan yang didasari adanya satu tujuan yaitu menghormati tamu. (2) Tari Galombang adalah simbol yang menggambarkan sanjungan, pujian, dan penghargaan terutama dari lingkungannya. (3) Pamer ketangkasan di mana masingmasing individu siap menghadapi tantangan (bela nagari), dalam perkembangan manusia ada berupa kecenderungan batin untuk mewujudkan diri untuk menjadi diri sendiri atau disebutnya individuasi (Jung dalam Agus, 2007: 26-29). (4) Kesadaran estetika atau berdasarkan nilai-nilai keindahan itu terlihat pada beberapa faktor yang secara visual ada dalam pertunjukan galombang tersebut. Secara visual dari keseluruhan pertunjukan 
itu akan terlihat adanya unsur-unsur keindahan yang dimaksud St. Thomas Aguinas yaitu: "kesempurnaan atau tanpa cela, proporsi atau keseimbangan dan kecemerlangan atau kejelasan" (George Dickie, 1971: 8). Apabila dilihat lebih jauh lagi, pertunjukan galombang itu mengakomodasi nilai-nilai keindahan masyarakat bersangkutan. Hal itu tampak dalam aturan pelaksanaan permainannya. (5) Galombang sebagai alat legitimasi, gengsi, martabat dan harga diri. Sebagai bagian dari kebudayaan terbentuk suatu sistem norma dan nilai yang terorganisasi, menjadi pegangan dan kebanggaan bagi masyarakat. (6) Kedatangan rombongan tamu, penghulu ataupun guru silat yang demikian menggambarkan suatu kebesaran sebagai pemimpin suatu wilayah tertentu atau nagari atau suatu suku. Dalam hal ini mereka akan mengartikan bahwa tamu itu adalah seorang penghulu, dengan segala kebesarannya. Kebesaran yang dimaksud ialah paling tidak terlihat dari pakaian kebesaran, pendamping, dan termasuk prajurit raja atau penghulu itu sendiri, yaitu para pemain galombang. Pada sisi lain sesungguhnya permainan galombang itu sendiri terlihat sebagai icon. Icon adalah sebuah simbol dari lambang kebesaran. Masyarakat sepakat mengartikan bahwa tamu yang datang adalah pembesar, maka kedatangannya disambut dengan permainan Galombang. Maka di sini berarti bahwa permainan galombang itu sendiri merupakan permainan kebesaran yang disesuaikan artinya dengan kebesaran martabat, yaitu martabat seorang tamu atau penghulu. Dari kenyataan yang demikian maka permainan galombang tersebut pada hakikatnya merupakan sebuah simbol, yang arti simboliknya adalah suatu kebesaran.

Melalui pertunjukan Galombang, tersimbol kekuatan dari suatu kebesaran yang tidak bisa dianggap remeh oleh kekuatan atau kebesaran pihak lain, adalah dikarenakan sifat kebersamaan atau gotong royong, etos kerja yang kuat, kesantunan dan kepatuhan kepada sang guru. Demikian pula peranannya sebagai tata pergaulan dalam kehidupan adat, masih saja bertahan hingga saat ini. Terutama tata pergaulan yang berhubungan dengan tata-cara seremonial adat yang berkaitan khususnya dengan jawatan yaitu penghulu.

\section{Kepustakaan}

Amran, Rusli. 1981. Padang Riwayatmu Dulu. Jakarta: Yasaguna.

Dieter Evers, Hans dan Korf, Ridger. 2002. Terjemahan Zulfahmi. Urbanisasi di Asia Tenggara: Makna dan Kekuasaan dalam Ruang-ruang Sosial. Jakarta: Yayasan Obor Indonesia.

Endang Caturwati. 2004. Seni dalam Dilema Industri: Sekilas Tentang Perkembangan Pertunjukan Tari Sunda. Yogyakarta: Yayasan Aksara Indonesia.

Carl Gustav Jung. 2007. Terjemahan Agus Cremes. Menjadi Diri Sendiri:Pendekatan Psikologi Analitis. Jakarta: Gramedia.

George, Dickie. 1971. Aesthetics: An Introduction. Indiana: Bobbs-Merril Company.

Hamka. 2006. Islam dan adat Minangkabau. Kuala Lumpur: Pustaka Dini SDN BHD.

Hartati. 1999. Tari Galombang Sebagai Penyambutan Tamu di Ampalu Kabupaten Padang Pariaman" Padangpanjang: STSI Press.

Haryono, Timbul. 2009. Seni dalam Dimensi, Bentuk, Ruang dan Waktu. Jakarta: Wedatama Widya Sastra.

Hatta Rajasa, M. "Memaknai Kemerdekaan dan Perspektif Pembinaan Karakter Bangsa”. http://www.setneg.go.id/

Holt, Claire. 1967. Art. In Indonesia: Countinuities and Change. Ithaca New York: Cornell University Press.

Mansoer, MD. 1970. Sejarah Ringkas Minangkabau. Jakarta: Bhratara.

Navis. 1984. Alam Takambang Jadi Guru: Adat dan Budaya Minangkabau. Jakarta: Grafiti Press.

Nerosti. 1992. "Tari Galombang dalam Masa Transisi". Laporan Penelitian. Padang: Universitas Negeri Padang.

Padang Dalam Angka. 2008. Padang: Badan Statistik.

Royce. 1977. The Antrophology of Dance. Bloomington and London: Indiana University Press. 